\title{
Avaliação das habilidades de metarrepresentação em crianças de sete a oito anos*****
}

\author{
Assessment of self-representation abilities in seven-eight year old \\ children
}

\begin{abstract}
Luciana Regina de Lima Carvalho* Fabiola Ferrer del Nero Mecca** Ida Lichtig***
\end{abstract}

\author{
*Fonoaudióloga. Mestranda em \\ Comunicação Humana pelo \\ Departamento de Fisioterapia, \\ Fonoaudiologia e Terapia Ocupacional \\ da Faculdade de Medicina da \\ Universidade de São Paulo. Endereço \\ para correspondência: \\ Rua Olga Benário, 53 - São Paulo - SP - \\ CEP 02875-070 \\ (lurelica@gmail.com). \\ **Fonoaudióloga. Doutora em \\ Comunicação Humana pelo \\ Departamento de Fisioterapia, \\ Fonoaudiologia e Terapia Ocupacional \\ da Faculdade de Medicina da \\ Universidade de São Paulo. Docente \\ do Curso de Fonoaudiologia da \\ Universidade de Mogi das Cruzes. \\ ***Fonoaudióloga. Livre-Docente. \\ Professora Associada do Curso de \\ Fonoaudiologia do Departamento de \\ Fisioterapia, Fonoaudiologia e Terapia \\ Ocupacional da Faculdade de Medicina \\ da Universidade de São Paulo. \\ ****Trabalho Realizado no \\ Departamento de Fisioterapia, \\ Fonoaudiologia e Terapia Ocupacional \\ da Faculdade de Medicina da \\ Universidade de São Paulo. Trabalho \\ de Iniciação Científica com bolsa \\ FAPESP (Processo $n^{\circ}$ 04/11803-8)
}

Artigo Original de Pesquisa

Artigo Submetido a Avaliação por Pares

Conflito de Interesse: não

\begin{abstract}
Background: Theory of Mind. Aim: the purpose of this study was to assess the self-representation abilities in 7-8 year old children and to verify the relationship between the Theory of Mind and language. Method: subjects of this study were 100 children - 50 boys and 50 girls - with ages between 7:2 and 8:11, divided in four groups: 7-year-old children with no communication deficits (Group 1), with 37 subjects; 7-yearold children with phonological retard (Group 2), with 13 subjects; 8-year-old children with no communication deficits (Group 3), with 46 subjects; and 8- year- old children with phonological retard (Group 4), with 4 subjects. All of the subjects were students of a municipal school in the city of São Paulo and were submitted to speech, language and hearing tests prior to the assessment of the self-representation abilities. The assessment of the self-representation abilities is composed by four tests proposed by Fernandes (2002) and adapted by Mecca (2005). Results: $88 \%$ of the 7 -year-old subjects passed the self-representation abilities test; $92 \%$ of the 8-year-old subjects also passed the same test. No statistically significant differences were found between gender, age or group. Conclusion: generally, children around 7 years have already acquired the Theory of Mind, however this acquisition can take longer and occur at other ages. The type of interaction and the presence of abstract elements during conversation can have an influence on the children's performance in tasks involving the theory of mind.
\end{abstract}

Key Words: Children; Language; Assessment.

\section{Resumo}

Tema: Teoria da Mente. Objetivo: o objetivo deste estudo foi verificar os aspectos metarrepresentacionais em crianças de 7 a 8 anos e investigar as relações entre linguagem e Teoria da Mente. Método: participaram da pesquisa 100 crianças - 50 meninos e 50 meninas - com idades entre 7:2 e 8:11, divididas em quatro grupos: crianças de sete anos sem alterações comunicativas (Grupo1), compostas por 37 sujeitos; crianças de sete anos com atraso fonológico (Grupo 2), composto por 13 sujeitos; crianças de oito anos sem alterações comunicativas (Grupo 3), composto por 46 sujeitos; e, crianças de oito anos com atraso fonológico (Grupo 4), composto por 4 sujeitos. Todos os sujeitos são alunos de uma escola municipal localizada na região metropolitana de São Paulo e passaram por triagens de fala, linguagem e audição, além da avaliação da metarrepresentação, que é composta por quatro testes. Utilizou-se para a avaliação da metarrepresentação a prova de Teoria da Mente proposta por Fernandes (2002) e adaptada por Mecca (2005). Resultados: entre os sujeitos de sete anos, 88\% passaram na avaliação da metarrepresentação. Entre os sujeitos de oito anos, este índice foi de $92 \%$. Não foram encontradas diferenças significantes por sexo, idade ou grupo. Conclusão: em torno dos sete anos de idade a grande maioria das crianças adquiriu a Teoria da Mente, embora esta aquisição possa se estender além desta. A forma de interação e a presença de elementos abstratos durante a conversação podem influenciar o desempenho das crianças nas tarefas de Teoria da Mente.

Palavras-Chave: Crianças; Linguagem; Avaliação. 


\section{Introduction}

The Theory of Mind is defined as a series of representations resulting from a sophisticated system and from several abstract and interdependent entities, which enable a model capable of explaining, interpreting and predicting the human behavior. (Courtin \& Melot, 1998).

The term Theory of Mind is related to a selfrepresentation (Fernandes, 2002). That is, the representation of mental states, which is important for the linguistic development (Hale \& TagerFlusberg, 2003; Berguno \& Bowler, 2004; Fisher et al., 2005; Slade \& Ruffman, 2005).

Literature points out that the development of different components of Theory of Mind in normal children occurs between 3 and 5 years of age (BlijdHoogewys et al., 2003).

The self-representation may be investigated through false-belief tasks (Siegal \& Beattie, 1991), which are tasks that demand the understanding of situations where there is a problem seen by different perspectives: the perspective of the individuals who is facing the problem, and the one of the spectator who is seeing the situation from the outside. First order Theory of Mind tasks demand the comprehension that "one person thinks something" while second order Theory of Mind tasks demand the comprehension that "one person thinks that the other person thinks something" (Fernandes, 2002).

Although investigations about Theory of Mind are relevant to understand the acquisition and development of verbal language, there isn't yet a national description of the behavior of children without communicative disorders in tasks of Theory of Mind.

The purpose of this study is to investigate the Theory of Mind in children from seven to eight years old, with and without communicative disorders.

\section{Method}

One hundred subjects, 50 female and 50 male, ranging in age from $7 \mathrm{y} 2 \mathrm{~m}$ and $8 \mathrm{y} 11 \mathrm{~m}$ were selected. All subjects are students of a public school (Escola Municipal de Ensino Fundamental do Centro Educacional Unificado Butantã - CEU Butantã).

Subjects were divided in four groups after being submitted to speech, language and hearing assessments: 7 year-old children without communicative disorders (Group 1), composed by 37 subjects; 7 year-old children with phonological delay (Group 2), composed by 13 subjects; 8 yearold children without communicative disorders (Group 3), composed by 46 subjects; and 8 yearold children with phonological disorders (Group 4), composed by 4 subjects. Subjects belonging to Groups 1 and 3 (children without communicative disorders) passed all screening tasks; while subjects belonging to Groups 2 and 4 (children with phonological delay) failed the speech screening.

The research project was approved by the Ethics Committee of the University of São Paulo Medical School - CAPPesq - (research protocol number 934/04). After the selection of subjects and the signing of the informed consent term by the children's caregivers, the students were removed from the classroom and, one at a time, they were taken to a room where the screening tests were performed. In another moment, the researcher called the student to perform the self-representation assessment. All subjects were individually assessed. The average assessment time was 30 minutes.

Before the beginning of the screening tests, a sound pressure level measurement was conducted in the school in order to certify that the environmental noise would not interfere on the hearing screening test, assuring the ideal acoustic conditions for data collecting. The measurement was performed according to the criteria of Costa et al (2000) and the norms of ABNT (1987).

The language screening was performed using the book Hide-and-Seek of Eva Furnari. In this task the child was asked to develop a narrative from the sequence of pictures presented in the book. A pass in the task was considered when the child produced a cohesive narrative discourse coherent with the picture.

The speech screening was performed using the imitation task of the ABFW (Andrade, Béfi-Lopes, Fernandes \& Wertzner, 2000). A pass was considered when the child did not present any phonemic disorder.

The hearing screening was performed through the video-test "Quem Ouve Bem Aprende Melhor" (Russo \& Albernaz, 2001). The screening involved sounds equivalent to the frequencies of 500, 1000, 2000 and $4000 \mathrm{~Hz}$. Each frequency was represented by the sound of an animal and presented in different intensities varying from 20 to $5 \mathrm{db}(\mathrm{A})$, in a decreasing order. In this task the child received the following instruction: "You will see on TV the picture of four animals, the owl, the dog, the cat and the bird. Each one of them produces a different sound and you should raise your hand when you 
hear the sounds". A pass was considered when the child detected at least five of the seven stimuli presented for each frequency.

The material and criteria elaborated by Sparrevohn and Howie (1995), adapted to Portuguese by Fernandes (2002) and Mecca (2005) were used for the Theory of Mind assessment. The first three tests - inferred belief, other belief and explicit false-belief - referred to the narrative of a story, taped and edited in computer files format, together with the presentation of pictures in the monitor screen. The last test corresponded to the self-representation assessment - complete falsebelief - and included a live narrative of a story by the researcher with a simultaneous presentation of a box of candies with color pencils inside, used as a material generator of a "problem situation".

The use of a computer aimed to guarantee greater attention and collaboration of children than it would be gained using simple figures, as well as to assure the presentation order of figures, the quality of the images and also the way questions were asked to all subjects.

The stories told were:

\section{Inferred belief (IB):}

Slide 1: This is Marina.

Slide 2: This morning Marina saw her color pencils on the table and not in the drawer. Marina wants her color pencils.

Slide 3: Where will she look for them?

(correct response: on the table)

Other belief (OB):

Slide 1: This is Pedro.

Slide 2: Pedro wants to find his dog.

Slide 3: Pedro's dog may be hiding in the home or in the garden.

Slide 4: Where do you think Pedro's dog is hiding? if the child answers "in the home", the slide 5 is presented:

Slide 5: This is a good idea. But Pedro thinks his dog is in the garden.

if the child answers "in the garden", the slide 6 is presented:

Slide 6: This is a good idea. But Pedro thinks his dog is in the house.

Slide 7: Where will Pedro look for his dog first? (correct response: slide 5 - in the garden; slide 6 - in the house)
Explicit False-belief (EFB):

Slide 1: This is Lucia. Lucia wants to find her cat. Slide 2: Lucia's cat is in the bedroom.

Slide 3: But Lucia thinks her cat is in the kitchen. Slide 4: Where will Lucia look for her cat? (correct response: in the kitchen) Slide 5: Where in fact is the cat? (correct response: in the bedroom)

Complete False-belief / Self-representation (CFB):

The researcher picks up a box of "Mentos Ice" grape flavor and asks the child:

Researcher: "What is in here?"

(correct response: candy/Mentos/grape)

The researcher opens the Box and shows that there are no candies inside, but color pencils, and replies: Researcher: "No, they are color pencils".

The researcher puts the pencils back in the box, closes it, and then shows the picture of a man in the computer screen and informs the child:

Researcher: "This is my friend". The researcher waits for a response/commentary of the child in order to be sure that the child understood that that picture represented the researcher's friend. Afterwards, the researcher asks:

Researcher: "What is in here?"

(correct response: pencils)

Then, the researcher asks the subject about her friend:

Researcher: "Do you remember my friend?" (and shows the picture of her friend again). "He didn't see this box. I'll show him this box" (and points to the box and to the picture) "and I'll ask him what is in here".

Researcher: "What will he say?"

(correct response: candy/Mentos)

The researcher turns to the child and asks:

Researcher: "What is in the box?

(correct response: pencils).

A pass in the tests IB, OB, EFB and CFB was considered when the subject responded correctly to all questions. To pass the self-representation assessment, subject should pass the CFB test.

The data analysis criterion used in this research was the comparison between groups.

\section{Results}

All subjects passed the hearing screening.

Concerning the speech/language screenings, all subjects from Group 2 failed the speech screening, and three of them also failed the language 
screening. Al subjects from Group 4 failed the speech screening and none of them failed the language screening. All subjects from Groups 1 and 3 passed all screening tests.

For the statistical analysis, the Mann-Whitney Test was used in order to verify possible differences between the categories of the studied variables. The significance level adopted in this research was $5 \%(\mathrm{p}<0,05)$, and no significant statistical difference was found between the findings.

Around $85 \%$ of children from Group 1 passed the IB, OB and CFB tasks. In Group 2 this percentage was similar for the CFB task; however, subjects from Group 2 failed more in the IB and OB tasks when compared to subjects from Group 1. The performance of Group 3 was approximately $90 \%$ in the IB and CFB tasks, and in the OB task, this percentage decreased to $67 \%$. Group 4 presented the best performance in the self-representation task (CFB task), in which all subjects passed. Nevertheless, the performance of subjects in the IB and OB tasks did not vary in relation to the performance of the other groups. All children presented a low percentage of pass in the EFB task, which can be seen in Table 1.

In general, children from Group 1 presented better performance in Theory of Mind tasks than children from Group 2. Children from Group 3, however, presented better performance than children from Group 4 only in the IB task. Such differences were not statistically significant (Mann-Whitney Test).

In the self-representation assessment, four children from Group 1, two from Group 2 and four from Group 3 failed. That means that in Group 1, $10,8 \%$ of subjects failed the self-representation assessment, while $15,4 \%$ of subjects from Group 2 failed in this assessment; in Group 3, this percentage was $8,7 \%$. In Group 4, no subjects failed the self-representation assessment.

TABLE 1 - Distribution of the percentage of children who passed the tasks IB, OB, CFB and EFB.

\begin{tabular}{|c|c|c|c|c|}
\hline & IB & OB & EFB & CFB \\
\hline GROUP 1 & $86 \%$ & $84 \%$ & $56 \%$ & $85 \%$ \\
\hline GROUP 2 & $69 \%$ & $76 \%$ & $31 \%$ & $91 \%$ \\
\hline GROUP 3 & $89 \%$ & $67 \%$ & $39 \%$ & $100 \%$ \\
\hline GROUP 4 & $75 \%$ & $75 \%$ & $50 \%$ & $89 \%$ \\
\hline
\end{tabular}

TABLE 2. Statistical analysis of the performance of subjects according to the age.

\begin{tabular}{|c|c|c|c|c|c|c|c|c}
\hline & \multicolumn{2}{|c|}{ IB } & \multicolumn{2}{c|}{ OB } & \multicolumn{2}{c}{ EFB } & \multicolumn{2}{c}{ CFB } \\
\cline { 2 - 9 } & Failed & Passed & Failed & Passed & Failed & Passed & Failed & Passed \\
\hline 7 years & 9 & 41 & 9 & 41 & 25 & 25 & 6 & 44 \\
\hline 8 years & 6 & 44 & 16 & 34 & 30 & 20 & 4 & 46 \\
\hline Total & 15 & 85 & 25 & 75 & 55 & 45 & 10 & 90 \\
\hline P value & \multicolumn{2}{|c|}{$\mathrm{p}=0,605$} & \multicolumn{2}{c|}{$\mathrm{p}=0,227$} & \multicolumn{2}{c}{$\mathrm{p}=0,730$} \\
\hline
\end{tabular}

TABLE 3. Statistical analysis of the performance of subjects according the linguistic development.

\begin{tabular}{|c|c|c|c|c|c|c|c|c}
\hline & \multicolumn{2}{|c|}{ IB } & \multicolumn{2}{c|}{ OB } & \multicolumn{2}{c}{ EFB } & \multicolumn{2}{c}{ CFB } \\
\cline { 2 - 10 } & Failed & Passed & Failed & Passed & Failed & Passed & Failed & Passed \\
\hline Without delay & 10 & 73 & 21 & 62 & 44 & 39 & 8 & 75 \\
\hline Delayed & 5 & 12 & 4 & 13 & 11 & 6 & 2 & 15 \\
\hline Total & 15 & 85 & 25 & 75 & 55 & 45 & 10 & 90 \\
\hline P value & \multicolumn{2}{|c|}{$\mathrm{p}=0,260$} & \multicolumn{2}{c|}{$\mathrm{p}=0,908$} & $\mathrm{p}=0,449$ & $\mathrm{p}=0,890$ \\
\hline
\end{tabular}




\section{Discussion}

A great part of children from Groups 1 and 2 passed the Theory of Mind tests, corroborating with a number of studies (Wimmer \& Perner, 1983; Roazzi $\&$ Santana, 1999) that point out that until seven years of age, children completely acquire the ability of predict thoughts and feelings of other people. However, it's worth observing that a small number of children in this age group did not pass the CFB test, although they passed the IB and OB tests. This fact could indicate that the complete acquisition of the Theory of Mind for some children may go beyond the age of seven. With this purpose, the present study was reapplied with eight year-old children in order to verify if the percentage of 8 year-old children that pass the CFB test is higher than the percentage obtained with 7 year-old children. Nevertheless, the hypothesis that eight year-old children (Groups 3 and 4) would have a better performance in the CFB test than the seven year-old children (Groups 1 and 2) was not confirmed, once the performance of Groups 3 and 4 was similar to the performance of Groups 1 and 2 .

The findings of this research corroborate with the findings of Fernandes (2002), where Brazilian children were delayed in relation to international data. Further researches are necessary in order to define whether the acquisition of the Theory of Mind by Brazilian children is really delayed in comparison to European and American children, or if the differences found in this study are due to the lower socioeconomic conditions of the population analyzed, once all subjects were students of a public school from the periphery of the city.

It was observed a difference between the performance of groups of children with phonological delay (Groups 2 and 4) and the groups of children without communicative disorders (Groups 1 and 3), despite not being statistically significant, they reveal the existence of an interrelation between Theory of Mind and language development. Question is, does the Theory of Mind determine the language development or the language development leads to the Theory of Mind development? Therefore, further researches are necessary, in order to reveal the principles that guide the development of these cognitive functions.

Another fact that deserves attention is that children presented difficulties in the explicit falsebelief task - a task considered easy - and had good performance in the complete false-belief task, considered the most difficult one. This may be explained by the linguistic demand of the explicit falsebelief task, which may not be appropriate for the age group of the subjects.

The findings of this study reveal being of great utility for future researches in the area, once this study describes the behavior of Brazilian children in Theory of Mind tests, in order to establish a national parameter that is able to delimit the age of acquisition of Theory of Mind in Brazilian children.

\section{Conclusion}

The findings of this research indicated that: . At around seven years of age, the great majority of children had acquired the Theory of Mind, although this acquisition may be extended beyond this age;

. There were no significant statistical differences between the performance of the seven year-old group of children and the eight year-old one;

. The false-belief task was efficient to investigate the Theory of Mind in children;

. The way of interaction and the presence of abstract elements during the conversation may influence children's performance in Theory of Mind tasks. 


\section{References}

1. Courtin C, Melot AM. Development of theories of mind in deaf children. In: M. Marscharck (Ed.), Psychological perspectives on deafness; 1998. p. 79-102.

2. Fernandes FDM. Atuação fonoaudiológica com crianças com transtorno do espectro autístico (tese de livre docência), Universidade de São Paulo; 2002.

3. Hale CM, Tager-Flusberg H. The influence of language in Theory of Mind: a training study. Developmental Science. 2003;6(3):346-59.

4. Berguno G, Bowler DM. Communicative interactions, knowledge of a second language, and Theory of Mind in young children. Journal of Genetic Psychology. 2004;165(3): 293-309.

5. Fisher N, Happe F, Dunn J. The relationship between vocabulary, grammar, and false belief task performance in children with autistic spectrum disorders and children with moderate learning difficulties. Journal of Child Psychology and Psychiatry. 2005; 46(4): 409-19.

6. Slade L, Ruffman T. How language does (and does not) relate to theory of mind: A longitudinal study of syntax, semantics, working memory and false belief. British Journal of Developmental Psychology. 2005;23(1):117-41.

7. Bligd-Hoogewys EMA, Huyghen AMN, Van-Geert PLC, et al. The Theory of Mind story books: Construction and setting standard norms for an instrument measuring Theory of Mind in young children. Nederlands Tydschrift voor de Psychologie em haar Gresgebieden. 2003;58(2):19-33.

8. Siegal M, Beattie K. Where to look first for children's knowledge of false beliefs. Cognition. 1991;38:1-12.
9. Costa AS, De Martino E, Veloso S, Pires RMR. Programa de conservação auditiva em maternidades: resultados parciais referentes às medições do ruído das incubadoras. Revista Unicastelo. 2000;3(3):53-8.

10. Associação Brasileira de Normas Técnicas (ABNT). Níveis de ruído para o conforto acústico: NBR-10152. Rio de Janeiro; 1987.

11. Furnati E. Esconde-Esconde. São Paulo, Ática; 1980.

12. Andrade CRF, Béfi-Lopes DM, Fernandes FDM, Wertzner HF. ABFW teste de linguagem infantil nas áreas de fonologia, vocabulário, fluência e pragmática. Carapicuíba, Pró-Fono; 2000. p. 5-16.

13. Russo ICP, Mangabeira-Albernaz PL. Quem ouve bem aprende melhor (vídeo educativo), São Paulo; 2001.

14. Sparrevohn R, Howie PM. Theory of mind in children with autistic disorder: Evidence of developmental progression and the role of verbal ability. Journal of Child Psychology and Psychiatry. 1995;36:249-63.

15. Mecca FFN. Análise do vocabulário, da teoria da mente e do desempenho escolar de crianças surdas (tese de doutorado), Universidade de São Paulo; 2005.

16. Wimmer H, Perner J. Beliefs about beliefs: Representation and contraining function of wrong beliefs in young children's understanding of deception. Cognition, 1983;13:103-128.

17. Roazzi A, Santana SM. Efeito da idade, sexo e uso de atores animados e inanimados na inferência de estados mentais. Psicologia: Reflexão e Crítica. 1999;12:307-30. 